PEREIRA, FT; OLIVEIRA, JB; MUNIZ, PHPC; PEIXOTO, GHS; GUIMARÃES, RR; CARVALHO, DDC. 2019. Growth promotion and productivity of lettuce using Trichoderma spp. commercial strains. Horticultura Brasileira 37: 069-074. DOI - http://dx.doi.org/10.1590/S0102-053620190111

\title{
Growth promotion and productivity of lettuce using Trichoderma spp. commercial strains
}

\author{
Fabíola T Pereira ${ }^{1} \mathbb{D}$; Jessica B de Oliveira ${ }^{1} \mathbb{D}$; Paulo Henrique PC Muniz ${ }^{1} \mathbb{D}$; Gustavo Henrique S Peixoto \\ ${ }^{1} \mathbb{D}$; Roberli R Guimarães ${ }^{1} \mathbb{D}$; Daniel Diego C Carvalho ${ }^{1} \mathbb{D}$
}

${ }^{1}$ Universidade Estadual de Goiás (UEG), Ipameri-GO, Brazil; fabiolateodoro.p@gmail.com; jessicaborges114@hotmail.com; paulohenrique. muniz1@gmail.com; gugspeixoto@gmail.com; roberli.guimaraes@ueg.br; daniel.carvalho@ueg.br

\begin{abstract}
The aim of this study was to evaluate four strains of Trichoderma spp. (T. harzianum IBLF $006 \mathrm{WP}$, T. harzianum IBLF $006 \mathrm{SC}$, T. harzianum ESALQ 1306 and T. asperellum URM 5911) for seedling growth promotion in laboratory and head lettuce yield in field conditions. The experiment was carried out in a completely randomized design with four treatments (strains): IBLF $006 \mathrm{WP}$ IBLF 006 SC, ESALQ 1306 and URM 5911 and a non-inoculated (without Trichoderma) control. Each treatment consisted of 200 seeds, arranged in four replicates. Lettuce seeds cv. Astra were treated with $2 \mathrm{~mL}$ Trichoderma suspension $\left(2.5 \times 10^{8}\right.$ conidia $\mathrm{mL}^{-1}$ per each 100 g seeds) and submitted to growth assay in laboratory up to 7 days after sowing. For field experiment, we opened furrows, which were manually sprayed with $5 \times 10^{7}$ conidia $\mathrm{mL}^{-1}$. Afterwards, seedlings were transplanted ( 4 to 6 leaves of head lettuce cv. Mauren) and harvested 40 days later. Each treatment consisted of four replicates (1.2 x $1.2 \mathrm{~m}, 16$ plants per plot) arranged in randomized blocks. In both experiments, a control without Trichoderma application was included, and we evaluated shoot length, root and total length, shoot, root and total fresh mass and shoot, root and total dry mass, shoot mass ratio, root mass ratio and shoot/root ratio. The germination (\%) was evaluated by laboratory tests, whereas in field experiment, height, stem diameter, head diameter, number of leaves and yield were evaluated. The T. harzianum strain ESALQ 1306 provided the best head lettuce growth rate in laboratory test, which was confirmed in field experiment, in which the productivity $\left(50.2 \mathrm{t} \mathrm{ha}^{-1}\right)$ was superior when compared to the other strains ( 41.38 to $\left.44.23 \mathrm{t} \mathrm{ha}^{-1}\right)$ and the control $\left(30.18 \mathrm{tha}^{-1}\right)$.
\end{abstract}

Keywords: Trichoderma harzianum, Trichoderma asperellum, Lactuca sativa, biological control, horticulture.

\section{RESUMO}

Promoção do crescimento e da produtividade de alface pelo emprego de cepas comerciais de Trichoderma spp.

O objetivo deste trabalho foi avaliar quatro cepas de Trichoderma spp. (T. harzianum IBLF $006 \mathrm{WP}, T$. harzianum IBLF $006 \mathrm{SC}, T$. harzianum ESALQ 1306 e T. asperellum URM 5911) na promoção do crescimento de plântulas em laboratório e na produtividade de alface americana em campo. O delineamento experimental foi inteiramente casualizado com quatro tratamentos (cepas): IBLF 006 WP, IBLF 006 SC, ESALQ 1306 e URM 5911 e um tratamento sem inoculação com Trichoderma que foi incluído como testemunha. Cada tratamento teve 200 sementes, dispostas em quatro repetições. Para tanto, sementes de alface cv. Astra foram tratadas com $2 \mathrm{~mL}$ de suspensão de Trichoderma $\left(2,5 \times 10^{8}\right.$ conídios $\mathrm{mL}^{-1}$ para cada $100 \mathrm{~g}$ de sementes $)$ e submetidas a teste de crescimento em laboratório até os 7 dias após o semeio. Para o experimento em campo realizou-se a abertura dos sulcos, os quais receberam $5 \times 10^{7}$ conídios $\mathrm{mL}^{-1}$ com auxílio de um pulverizador manual, seguido de transplantio de mudas (4 a 6 folhas) de alface americana cv. Mauren e colheita aos 40 dias após o transplantio. Cada tratamento foi composto por quatro repetições (1,2 x 1,2 m, com 16 plantas em cada parcela) dispostas em blocos casualizados. Em ambos incluiu-se uma testemunha sem aplicação de Trichoderma. Avaliou-se o comprimento da parte aérea, da raiz e total, massas fresca e seca da parte aérea, da raiz e total, razão de massa da parte aérea, razão de massa da raiz e razão parte aérea/sistema radicular. No experimento em laboratório avaliou-se o percentual de germinação, enquanto que no experimento em campo avaliou-se a altura, diâmetro do caule, diâmetro da cabeça, número de folhas e produtividade. A cepa T. harzianum ESALQ 1306 proporcionou melhor crescimento de alface americana em laboratório, o que foi confirmado em campo, cuja produtividade $\left(50,2 \mathrm{t} \mathrm{ha}^{-1}\right)$ foi superior às demais cepas $\left(41,38 \mathrm{a} 44,23 \mathrm{tha}^{-1}\right)$ e à testemunha $\left(30,18 \mathrm{tha}^{-1}\right)$.

Palavras-chave: Trichoderma harzianum, Trichoderma asperellum, Lactuca sativa, controle biológico, horticultura.

\section{Received on January 25, 2018; accepted on January 24, 2019}

L ettuce is one of the most widely cultivated leaf vegetables in Brazil; it is grown by small farmers, being a crop of great economic and social importance. Due to wide adaptation to different climatic conditions, short cycle, low production cost, low susceptibility to several pests and diseases, and also post-marketing safety, this crop allows successive cultivations all year long (Medeiros et $a l$. , 2007). The state of Goiás is one of the main lettuce producers: in 2016, the state commercialized 1479 tons (CEASA-GO, 2016). The increasing population growth and constant changes in dietary habits make the consumer of leaf vegetables more demanding 
concerning product quality. That's why, lettuce consumption tends to increase and, consequently, the need to produce it in quantity and with superior quality (Barros Júnior et al., 2010).

Trichoderma fungus is considered a free-living soil microorganism, which survives in tropical and temperate regions, being three species ( $T$. harzianum, $T$. virens and $T$. viride) the most used in biological control of diseases and on growth promotion of several crops (Hoffmann et al., 2015). Many studies point out the use of Trichoderma to promote initial growth of many commercial crops, such as tomatoes and beans (Chacón et al., 2007; Guimarães et al., 2014), as well as an increase in grain yield and leaf crops (Azevedo Filho et al., 2011; Carvalho et al., 2015a).

The most common method of application of Trichoderma is seed treatment. However, for some crops which are initially installed in seedbeds, when aiming to colonize soil by certain strains of Trichoderma, treatment of substrate or cultivation soil per application via furrow or superficial is an efficient method (Carvalho et al., 2015b).

Some isolates of Trichoderma provide plant growth stimulus, producing antibiotics, enzymes and metabolites, whose activities are comparable to plant hormones (Carvalho et al., 2011a). Several strains are excellent producers of secondary metabolites, being volatile or non-volatile and supposed biosynthesizers of nonribosomal peptides, terpenoids, pironas and polyketides and auxin analogs (Machado et al., 2012). Trichoderma spp. insertion into soils poor in mineral nutrients increases the solubilization of these nutrients. The same act as root growth biostimulant, increasing the assimilation of essential nutrients for the plant and contributing to obtain greater productivity, besides promoting root system protection against soil pathogens (Benítez et al., 2004). Such insertion is highly desirable because, in addition to the described benefits, it is possible to reduce or abolish the use of highly soluble chemical fertilizers, which for sustainable agricultural production cause damages to the environment (Azarmi et al., 2011).

Many studies on using live strains for the treatment of seeds and substrates for initial growth promotion of several crops or even in disease control can be found in literature. However, knowledge gaps concerning potential productivity of lettuce with live strains of Trichoderma spp. can be verified. The aim of this study was to evaluate four commercial products based on Trichoderma spp. in seedling growth promotion and head lettuce productivity in field.

\section{MATERIAL AND METHODS}

\section{Evaluated commercial strains}

The commercial strains evaluated in this study were Trichoderma harzianum IBLF 006 WP (Ecotrich WP; Ballagro Agro Tecnologia Ltda., Piracaia-SP, Brazil), Trichoderma harzianum IBLF 006 SC (Predatox SC; Ballagro Agro Tecnologia Ltda., Piracaia-SP, Brazil), Trichoderma harzianum ESALQ 1306 (Trichodermil; Koppert Biological Systems, Piracicaba-SP, Brazil) and Trichoderma asperellum URM 5911 (Quality WG; Laboratório de BioControle Farroupilha Ltda, Patos de Minas-MG, Brazil).

Initial growth of lettuce seedling using seed treatment with suspension of Trichoderma spp.

Head lettuce seeds, cv. Astra, were treated with $2 \mathrm{~mL}$ of Trichoderma suspension $\left(2.5 \times 10^{8}\right.$ conidia $\mathrm{mL}^{-1}$ for each $100 \mathrm{~g}$ seeds). Afterwards, the seeds were uniformly distributed on blotting paper sheets, contained in gerbox-type transparent acrylic boxes (11 x 11 $\mathrm{cm})$. Then, these seeds were kept in a BOD type seed germinator (Fanem $347^{\circledR}$ ), at $25^{\circ} \mathrm{C}$, for seven days. We used completely randomized experimental design, with four treatments (strains): IBLF 006 WP, IBLF 006 SC, ESALQ 1306 and URM 5911. One treatment, without Trichoderma inoculation, was included as control. In each treatment, 200 seeds were divided into four replicates (Gerbox) of 50 seeds (Carvalho et al., 2011b).

Germination (\%) was obtained by evaluating normal seedlings (absence of necrosis and pathogen in seedlings, seminal and secondary roots without deformation and discounting the dead seeds), shoot length (SL), root length (RL), total length $(\mathrm{TL}=\mathrm{SL}+\mathrm{RL})$, shoot fresh mass (SFM), root fresh mass (RFM), total fresh mass (TFM = SFM + RFM), shoot dry mass (SDM), root dry mass $(\mathrm{RDM})$, total dry mass $(\mathrm{BIO}=$ $\mathrm{SDM}+\mathrm{RDM}$ ), shoot mass ratio (SMR $=\mathrm{SDM} / \mathrm{BIO})$, root mass ratio $(\mathrm{RMR}=$ $\mathrm{RDM} / \mathrm{BIO})$ and shoot/root ratio $(\mathrm{S} / \mathrm{R}=$ $\mathrm{SDM} / \mathrm{RDM}$ ). In order to obtain SDM and RDM, shoots and roots were taken out and dried in an oven at $65^{\circ} \mathrm{C}$ until constant mass in order to obtain values in milligrams.

Productivity of lettuce plants and their components in field using planting furrow treatment with suspension of Trichoderma spp.

The experiment was carried out in an experimental area at Universidade Estadual de Goiás, Campus Ipameri, (17\%43'02' 'S, 48 08'37'W, $794 \mathrm{~m}$ ), in 2017, in Typic Hapludox. The soil presented the following chemical properties: $\mathrm{pH}$ in $\mathrm{CaCl}_{2}=5.7 ; \mathrm{MO}=$ $22.7 \mathrm{~g} \mathrm{dm}^{-1} ; \mathrm{P}=27.1 \mathrm{mg} \mathrm{dm}^{-1} ; \mathrm{K}=0.31$ cmolc dm $^{-1} ; \mathrm{Ca}=2.70$ cmolc $_{\mathrm{cm}}^{-1} ; \mathrm{Mg}=$ $1.10 \mathrm{cmol}_{\mathrm{c} \mathrm{dm}}{ }^{-1} ; \mathrm{H}+\mathrm{Al}=2.50 \mathrm{cmol}_{\mathrm{c} \mathrm{dm}}{ }^{-1}$; $\mathrm{S}=2.7 \mathrm{mg} \mathrm{dm}^{-1} ; \mathrm{B}=0.26 \mathrm{mg} \mathrm{dm}^{-1} ; \mathrm{Fe}=$ $43.7 \mathrm{mg} \mathrm{dm}^{-1} ; \mathrm{Mn}=35.3 \mathrm{mg} \mathrm{dm}^{-1} ; \mathrm{Cu}=$ $2.31 \mathrm{mg} \mathrm{dm}^{-1} ; \mathrm{Zn}=21.7 \mathrm{mg} \mathrm{dm}^{-1}$ and the following textural composition: clay $=$ $320 \mathrm{~g} \mathrm{~kg}^{-1}$; silt $=200 \mathrm{~g} \mathrm{~kg}^{-1}$ and sand $=$ $480 \mathrm{~g} \mathrm{~kg}^{-1}$. Throughout the experiment, manual irrigation was performed daily.

The experiment was installed in a $40.8 \mathrm{~m}^{2}$ area $(34.0 \times 1.2 \mathrm{~m})$; soil was plowed and harrowed. Afterwards, seedbeds were prepared with a plow. Chemical fertilizations, as well as soil correction, were done according to Yuri et al. (2002). Then, furrows were opened and $40 \mathrm{~mL}$ of Trichoderma spp. suspension $\left(5 \times 10^{7}\right.$ conidia $\left.\mathrm{mL}^{-1}\right)$ was applied per linear meter using a manual sprayer $(550 \mathrm{~mL})$, totalizing $2 \times 10^{9}$ conidia per linear meter in the furrow (Carvalho et al., 2011a).

Right after spray application, head lettuce seedlings, cv. Mauren with 4 - 6 leaves, grown in 200-cell styrofoam trays, filled with inert substrate, based on peat, carbonized rice chaff, vermiculite and ashes, were manually transplanted 
(4 plants per 1.2 linear meter). The experimental design was of randomized blocks with four treatments (strains): IBLF 006 WP, IBLF 006 SC, ESALQ 1306 and URM 5911 and one control without Trichoderma spp. inoculation. Each treatment was composed of four experimental plots with four planting lines, $1.2 \times 1.2 \mathrm{~m}$ total area with 16 plants spaced $0.3 \times 0.3 \mathrm{~m}$, plus $0.5 \mathrm{~m}$ of a seedbed without lettuce planting for separation between plots.

Forty days after seedling transplant, four central plants of each plot (useful area) were manually harvested to measure height $(\mathrm{H})$, stem diameter (SD), head diameter (HD), number of leaves (NL), shoot fresh mass (SFM), root fresh mass (RFM), total fresh mass (TFM), shoot dry mass (SDM), root dry mass (RDM), total biomass (BIO), shoot mass ratio (SMR), root mass ratio (RMR), shoot/root ratio $(\mathrm{S} / \mathrm{R})$ and productivity, using a caliper, a precision scale and a graduated scale. One control treatment was included in order to compare the treatments. Weed control was manually performed. The authors did not verify any pests or diseases.

\section{Statistical analysis}

Experimental data were submitted to variance analysis (ANOVA) and to Scott-Knott test $(\mathrm{P} \leq 0.05)$, using computer statistical software SISVAR 5.3 (FERREIRA, 2011).

\section{RESULTS AND DISCUSSION}

In relation to germination percentage (GP), T. harzianum strain ESALQ 1306 and T. harzianum IBLF 006 SC were superior to the other treatments, providing $93.50 \%$ and $93 \%$ of $\mathrm{PG}$. Followed by treatments $T$. harzianum IBLF $006 \mathrm{WP}$ and $T$. asperellum URM 5911 and the control, which showed the lowest PG (82\%) (Table 1). $T$. harzianum strain ESALQ 1306 showed a superior increase when compared with the other treatments in relation to shoot length $(\mathrm{SL}=2.46 \mathrm{~cm})$, root length $(\mathrm{RL}=$ $4.96 \mathrm{~cm})$ and total length $(\mathrm{TL}=7.41$ $\mathrm{cm})$. For the other strains values of SL, $\mathrm{RL}$ and TL ranged from 1.76 to 1.83 $\mathrm{cm}, 3.78$ to $4.27 \mathrm{~cm}, 5.62$ to $6.03 \mathrm{~cm}$, respectively. Control showed the lowest values of SL, RL and TL: 1.54, 3.27 and $4.82 \mathrm{~cm}$, respectively.

For total fresh and total dry mass, $T$. harzianum strain ESALQ 1306, again, showed to be superior to the other treatments, considering TFM of 23.62 $\mathrm{mg}$ and $\mathrm{BIO}$ of $1.55 \mathrm{mg}$, respectively. The control treatment showed the lowest values, $12.40 \mathrm{mg}$ and $0.76 \mathrm{mg}$ for TFM and $\mathrm{BIO}$, respectively. In relation to ratios, T. asperellum URM 5911 and the control showed lower S/R (2.73 and 2.61 , respectively) inferior to the other treatments which value of $\mathrm{S} / \mathrm{R}$ ranged from 2.85 to 2.95 (Table 1 ).

In relation to plant height $(\mathrm{H})$ and stem diameter (SD), T. harzianum strain ESALQ 1306 was superior than the other strains $(18.65 \mathrm{~cm}$ and 15.28 $\mathrm{mm}$ ), followed by T. asperellum URM $5911(15.75 \mathrm{~cm}$ and $14.38 \mathrm{~mm})$, which was the second best treatment (Table 2). Evaluating head diameter (HD) and number of leaves (NL), T. harzianum strain ESALQ 1306 was superior to the other treatments, providing $13.50 \mathrm{~cm}$ and 28.12 leaves. The other strains were superior when compared to the control (10.46 cm and 22.45 leaves), with values for HD ranging from 12.06 to $12.59 \mathrm{~cm}$ and NL ranging from 25.31 to 25.75 . For fresh and dry mass, T. harzianum ESALQ 1306 was superior to the other treatments, showing TFM of $462.0 \mathrm{~g}$ and BIO of $18.92 \mathrm{~g}$, respectively. The control provided the lowest values, $276.98 \mathrm{~g}$ and $10.26 \mathrm{~g}$ for TFM and BIO, respectively. For ratios, no differences among treatments for SMR, RMR and $\mathrm{S} / \mathrm{R}$ were no noticed. For productivity, $T$. harzianum ESALQ 1306 was superior to the other ones $\left(50.20 \mathrm{t} \mathrm{ha}^{-1}\right)$, followed by T. asperellum URM 5911, T. harzianum IBLF $006 \mathrm{SC}$ and T. harzianum IBLF 006 WP which provided about 44.23 , 42.77 and $41.38 \mathrm{t} \mathrm{ha}^{-1}$, respectively. All strains were superior compared with the control, which provided $30.18 \mathrm{tha}^{-1}$ (Table 2).

Seed germination and seedling vigor are decisive factors for crop production success and presence of hormones, promoters and growth inhibitors are essential for germination physiological process (Ferreira \& Borghetti, 2004).

The strains used in this study provided positive and beneficial effects on lettuce seed germination. These results were already expected, according to the information found in literature (Oliveira et al., 2018), since seed germination can be favored by the action of Trichoderma spp. strains. This situation might be related to the fact that lettuce seeds have lower concentrations of reserve substances for germinative process when compared with grainproducing species. Thus, germination process and initial seedling development seem to be stronger influenced by exogenous growth regulators, when associated with microorganisms (Schlindwein et al., 2008). Germination (\%), emergence and emergence speed index are promoted when seeds are inoculated with Trichoderma spp. This fact is attributed to growth regulator liberation mechanism and nutrient solubilization (Hajieghrari, 2010; Wesam et al., 2017).

Those seeds treated with Trichoderma spp. presented length gain. Probably, the most likely mechanism to promote initial growth is via direct, it means, production of hormones or analogues (Wesam et al., 2017). We noted that the seeds showed low or no occurrence of harmful pathogens to germination, refuting indirect initial growth promotion, through harmful pathogens to germination and emergence.

For fresh mass and total biomass accumulations, the strain ESALQ 1306 was also superior to the other treatments. However, the other strains also showed results superior to the control. This can be explained in the study carried out by Chacón et al. (2007), in which these authors state that tomato plants inoculated with $T$. harzianum showed increased root proliferation and, as a consequence, an increase in sanity and water and nutrient absorption capacity, promoting, as observed by Machado et al. (2012), an increase of fresh mass of several plant parts.

$\mathrm{H}$ and SD are productive variables, which allow greater separation capacity among evaluated strains when comparing with HD and NL. According to Trani et al. (2006), NL is a trait directly related to cultivation temperature and photoperiod. Due to this characteristic, 
Table 1. Characteristics of head lettuce seedlings, cv. Astra, treated with commercial strains of Trichoderma spp. Ipameri, UEG, 2017.

\begin{tabular}{|c|c|c|c|c|c|c|c|c|}
\hline Treatment & $\begin{array}{c}\text { Germination } \\
(\%)^{1}\end{array}$ & $\begin{array}{l}\text { Shoot length } \\
\text { (cm) }\end{array}$ & $\begin{array}{l}\text { Root length } \\
\text { (cm) }\end{array}$ & \multicolumn{2}{|c|}{$\begin{array}{l}\text { Total length } \\
\text { (cm) }\end{array}$} & $\begin{array}{l}\text { Shoot fresh } \\
\text { mass }(g)\end{array}$ & $\begin{array}{l}\text { Root fresh } \\
\text { mass (g) }\end{array}$ & $\begin{array}{c}\text { Total fresh } \\
\text { mass (g) }\end{array}$ \\
\hline $\begin{array}{l}\text { T. harzianum } \\
\text { IBLF } 006 \mathrm{WP}\end{array}$ & $90.00 \mathrm{~b}$ & $1.76 \mathrm{c}$ & $4.27 \mathrm{~b}$ & \multicolumn{2}{|c|}{$6.03 \mathrm{~b}$} & $12.14 \mathrm{c}$ & $4.94 \mathrm{c}$ & $17.09 \mathrm{c}$ \\
\hline $\begin{array}{l}\text { T. harzianum } \\
\text { IBLF } 006 \text { SC }\end{array}$ & $93.00 \mathrm{a}$ & $1.82 \mathrm{~b}$ & $3.86 \mathrm{c}$ & \multicolumn{2}{|c|}{$5.69 \mathrm{c}$} & $11.62 \mathrm{c}$ & $4.72 \mathrm{c}$ & $16.35 \mathrm{~d}$ \\
\hline $\begin{array}{l}\text { T. harzianum } \\
\text { ESALQ } 1306\end{array}$ & $93.50 \mathrm{a}$ & $2.46 \mathrm{a}$ & $4.96 \mathrm{a}$ & \multicolumn{2}{|c|}{$7.41 \mathrm{a}$} & $15.96 \mathrm{a}$ & $7.66 \mathrm{a}$ & $23.62 \mathrm{a}$ \\
\hline $\begin{array}{l}\text { T. asperellum } \\
\text { URM } 5911\end{array}$ & $85.50 \mathrm{c}$ & $1.83 \mathrm{~b}$ & $3.78 \mathrm{~d}$ & \multicolumn{2}{|c|}{$5.62 \mathrm{c}$} & $13.12 \mathrm{~b}$ & $5.45 \mathrm{~b}$ & $18.58 \mathrm{~b}$ \\
\hline Control & $82.00 \mathrm{~d}$ & $1.54 \mathrm{~d}$ & $3.27 \mathrm{e}$ & \multicolumn{2}{|c|}{$4.82 \mathrm{~d}$} & $7.97 \mathrm{~d}$ & $4.42 \mathrm{~d}$ & $12.40 \mathrm{e}$ \\
\hline \multirow[t]{2}{*}{ CV (\%) } & 3.41 & 7.50 & 6.85 & 5.7 & & 4.36 & 4.89 & 3.87 \\
\hline & $\begin{array}{c}\text { Shoot dry mass } \\
\text { (SDM) (mg) }\end{array}$ & $\begin{array}{c}s s \begin{array}{c}\text { Root dry mass } \\
(\text { RDM })(\mathrm{mg})\end{array} \\
\end{array}$ & \multicolumn{2}{|c|}{$\begin{array}{c}\text { Total biomass } \\
\left(\text { BIO) }(\mathrm{mg})^{2}\right. \\
\end{array}$} & \multicolumn{2}{|c|}{$\begin{array}{cc}\text { Shoot mass } & R \\
\text { ratio }(\mathrm{SMR})^{3} & \\
\end{array}$} & \multicolumn{2}{|c|}{$\begin{array}{cc}\text { Root mass ratio Shoot/root ratio } \\
(\mathrm{RMR})^{4} & (\mathrm{~S} / \mathrm{R})^{5} \\
\end{array}$} \\
\hline $\begin{array}{l}\text { T. harzianum } \\
\text { IBLF } 006 \mathrm{WP}\end{array}$ & $0.66 \mathrm{c}$ & $0.23 \mathrm{c}$ & 0.8 & & & $74 \mathrm{a}$ & $0.26 \mathrm{~b}$ & $2.87 \mathrm{a}$ \\
\hline $\begin{array}{l}\text { T. harzianum } \\
\text { IBLF } 006 \text { SC }\end{array}$ & $0.66 \mathrm{c}$ & $0.22 \mathrm{c}$ & 0.8 & & & $75 \mathrm{a}$ & $0.25 \mathrm{~b}$ & $2.95 \mathrm{a}$ \\
\hline $\begin{array}{l}\text { T. harzianum } \\
\text { ESALQ } 1306\end{array}$ & $1.15 \mathrm{a}$ & $0.40 \mathrm{a}$ & 1.5 & & & $74 \mathrm{a}$ & $0.26 \mathrm{~b}$ & $2.85 \mathrm{a}$ \\
\hline $\begin{array}{l}\text { T. asperellum } \\
\text { URM } 5911\end{array}$ & $0.78 \mathrm{~b}$ & $0.29 \mathrm{~b}$ & 1.0 & & & $73 \mathrm{~b}$ & $0.27 \mathrm{a}$ & $2.73 \mathrm{~b}$ \\
\hline Control & $0.55 \mathrm{~d}$ & $0.21 \mathrm{~d}$ & 0.7 & & & $73 \mathrm{~b}$ & $0.27 \mathrm{a}$ & $2.61 \mathrm{~b}$ \\
\hline CV (\%) & 3.76 & 4.12 & 3.2 & & & .19 & 3.35 & 4.46 \\
\hline
\end{tabular}

Averages followed by same lowercase letters in the column do not differ statistically, Scott-Knott test (P $\leq 0.05) ;{ }^{1}$ emergence at 7 days after sowing date; ${ }^{2} \mathrm{BIO}=\mathrm{SDM}+\mathrm{RDM} ;{ }^{3} \mathrm{SMR}=\mathrm{SDM} / \mathrm{BIO} ;{ }^{4} \mathrm{RMR}=\mathrm{RDM} / \mathrm{BIO} ;{ }^{5} \mathrm{~S} / \mathrm{R}=\mathrm{SDM} / \mathrm{RDM}$.

the variables HD and NL may be directly related to weather conditions, and the strains may cause only secondary effects on lettuce cultivars. In relation to SD, this characteristic defines seedling's field performance after planting (Souza et al., 2006), due to the ability to form new roots, a fact that is directly influenced by rhizosphere colonized by Trichoderma spp. with consequences on productivity (Carvalho et al., 2011a).

Values of H, SD, HD and NL were similar to the ones obtained in other studies with head lettuce (Table 2). The study carried out by Blind \& Silva Filho (2015), for instance, obtained 12.1 to $17.5 \mathrm{~cm}$ for HD of head lettuce cv. Balsamo. Santi et al. (2013) obtained SD ranging from 16 to $18 \mathrm{~mm}$ and NL ranging from 24.1 to 28.2 in head lettuce fertilized with filter cake. The treatments with Trichoderma spp. resulted, in relation to the control, a gain of 41 to $91 \%$ of $\mathrm{H}$, highlighting growthpromoting effect of the used strains. Silva et al. (2015), using different isolates of Trichoderma spp., observed similar effect; the increase in plant height was up to $34 \%$ in relation to the control, though.

Although fresh mass of plants is a less frequent component of evaluation in scientific studies on plant growth promotion, the authors highlight the importance to evaluate the strain effect on obtaining root fresh mass since it exploits a greater soil volume and they are also important in plant adaptation in environments with lower quantity of nutrients (Hartwigsen \& Evans, 2000).

So, considering that many strains of Trichoderma ssp. can help in nutrient solubilization (Benítez et al., 2004), the authors verified that $T$. harzianum ESALQ 1306 has potential to act as a nutrient solubilizer. Thus, we verified that the statistical superiority of $T$. harzianum ESALQ 1306 in laboratory for RFM, SFM, TFM, RDM, SDM and total biomass was also reproduced in field. One explanation for this event lies in the fact that, when one strain of Trichoderma establishes a relationship with rizosphere, plant growth is stimulated. This growth is related to rhizosphere competence, it means, the capacity the strains have to colonize the plant rizosphere and not only to produce growth hormones or analogues (Carvalho et al., 2011a).

Carvalho et al. (2015b) stated that, after being applied to a soil in which beans were grown, the strain of T. harzianum ESALQ 1306 was recovered, after the crop cycle, showing populations which ranged from 50 to $100 \mathrm{UFC} / \mathrm{g}$ soil. Moreover, not only the ability to colonize roots, but plant growth promotion also depends strongly 
on the interaction between the isolate and the tested plant species, as well as the conditions of the experiment conduction.

For lettuce productivity, treatment with $T$. harzianum ESALQ 1306 was considered satisfactory $\left(50 \mathrm{t} \mathrm{ha}^{-1}\right)$, since the average of head lettuce productivity using organic fertilizers is higher than $43.1 \mathrm{t} \mathrm{ha}^{-1}$, according to Sediyama et al. (2016). The other strains had productivity inferior than the productivity of ESALQ 1306, ranging from 41 to $44 \mathrm{t} \mathrm{ha}^{-1}$. The other strains were superior to the control $\left(30.18 \mathrm{t} \mathrm{ha}^{-1}\right)$, though. Similar productivities were found by Yuri et al. (2002), in head lettuce cultivars (Cassino, Legacy, Lucy Brown, Lorca, Lady and Raider) grown in south region of Minas Gerais at $800 \mathrm{~m}$ altitude, in typic distrophic Red Latosol, with a commercial production from 28.9 to $42.6 \mathrm{t} \mathrm{ha}^{-1}$ of harvest in March.

Thus, the strains IBLF 006 and URM
5911 could not be ruled out, because not all the efficient bioagents in promoting crop growth have equal efficiency for controlling diseases (Carvalho et al., 2015a,b).

In relation to the ratios in the laboratory experiment, the treatments with $T$. asperellum and the control were inferior to the other treatments for SMR and S/R; the authors suppose that the reduced biomass allocation to root system in seedlings treated with T. asperellum can be related to water availability to seedlings, since these seedlings were irrigated daily during the test with gerbox and, no water restriction was noticed (Guimarães et al., 2014). Contrary to what was observed in the laboratory, the seedlings did not obtain significant difference in relation to ratios in field experiment. This can be explained by the fact that Trichoderma fungus has differential reaction depending on the environment to which it is submitted (Akrami et al., 2011).

The results of head lettuce growth promotion showed in the treatment with T. harzianum ESALQ 1306 in laboratory were confirmed in the field when productivity and their components were evaluated. The authors recommend the use of strain T. harzianum ESALQ 1306 for growth promotion and head lettuce productivity, since the use of this strain for growing soil treatment provided an increase in productivity.

\section{ACKNOWLEDGEMENTS}

The authors thank to Scholarship Program of Research Productivity (PROBIP) of Universidade Estadual de Goiás (UEG), to Coordination of Improvement of Higher Education Personnel (CAPES) for the master scholarship granted and to Ballagro Agro Tecnologia Ltda.

Table 2. Characteristics of head lettuce cv. Mauren treated with commercial strains of Trichoderma spp. Ipameri, UEG, 2017.

\begin{tabular}{|c|c|c|c|c|c|c|c|}
\hline Treatment & $\begin{array}{l}\text { Height } \\
(\mathrm{cm})\end{array}$ & $\begin{array}{l}\text { Stem diameter } \\
(\mathrm{mm})\end{array}$ & $\begin{array}{c}\text { Head } \\
\text { diameter }(\mathrm{cm})\end{array}$ & $\begin{array}{l}\text { Number of } \\
\text { leaves }\end{array}$ & $\begin{array}{l}\text { Shoot fresh } \\
\text { mass (g) }\end{array}$ & $\begin{array}{l}\text { Root fresh } \\
\text { mass (g) }\end{array}$ & $\begin{array}{l}\text { Total fresh } \\
\text { mass (g) }\end{array}$ \\
\hline $\begin{array}{l}\text { T. harzianum } \\
\text { IBLF } 006 \text { WP }\end{array}$ & $14.12 \mathrm{c}$ & $13.66 \mathrm{c}$ & $12.37 \mathrm{~b}$ & $25.75 \mathrm{~b}$ & $372.50 \mathrm{~b}$ & $8.08 \mathrm{c}$ & $380.58 \mathrm{~b}$ \\
\hline $\begin{array}{l}\text { T. harzianum } \\
\text { IBLF } 006 \text { SC }\end{array}$ & $13.78 \mathrm{c}$ & $13.80 \mathrm{c}$ & $12.06 \mathrm{~b}$ & $25.31 \mathrm{~b}$ & $385.00 \mathrm{~b}$ & $7.95 \mathrm{c}$ & $392.95 \mathrm{~b}$ \\
\hline $\begin{array}{l}\text { T. harzianum } \\
\text { ESALQ } 1306\end{array}$ & $18.65 \mathrm{a}$ & $15.28 \mathrm{a}$ & $13.50 \mathrm{a}$ & $28.12 \mathrm{a}$ & $451.87 \mathrm{a}$ & $10.48 \mathrm{a}$ & $462.35 \mathrm{a}$ \\
\hline $\begin{array}{l}\text { T. asperellum } \\
\text { URM } 5911\end{array}$ & $15.75 \mathrm{~b}$ & $14.38 \mathrm{~b}$ & $12.59 \mathrm{~b}$ & $25.43 \mathrm{~b}$ & $398.12 b$ & $9.07 \mathrm{~b}$ & $407.20 \mathrm{~b}$ \\
\hline Control & $9.77 \mathrm{~d}$ & $10.70 \mathrm{~d}$ & $10.46 \mathrm{c}$ & $22.45 \mathrm{c}$ & $271.62 \mathrm{c}$ & $5.31 \mathrm{~d}$ & $276.98 \mathrm{c}$ \\
\hline \multirow[t]{2}{*}{ CV (\%) } & 4.78 & 6.24 & 6.96 & 4.99 & 13.89 & 16.63 & 13.69 \\
\hline & $\begin{array}{l}\text { Shoot dry } \\
\text { mass (mg) }\end{array}$ & $\begin{array}{c}\text { Root dry mass } \\
(\mathbf{m g})\end{array}$ & $\begin{array}{l}\text { Total biomass } \\
\text { (BIO) (mg) }{ }^{1}\end{array}$ & $\begin{array}{c}\text { Shoot mass } \\
\text { ratio }(\mathrm{SMR})^{2}\end{array}$ & $\begin{array}{c}\text { Root mass } \\
\text { ratio }(\mathrm{RMR})^{3}\end{array}$ & $\begin{array}{c}\text { Shoot/root ratio } \\
(\mathbf{S} / \mathbf{R})^{4}\end{array}$ & Yield (t/ha) \\
\hline $\begin{array}{l}\text { T. harzianum } \\
\text { IBLF } 006 \text { WP }\end{array}$ & $13.89 \mathrm{~b}$ & $0.74 \mathrm{c}$ & $14.64 \mathrm{~b}$ & $0.94 \mathrm{a}$ & $0.05 \mathrm{a}$ & $20.15 \mathrm{a}$ & $41.38 \mathrm{~b}$ \\
\hline $\begin{array}{l}\text { T. harzianum } \\
\text { IBLF } 006 \text { SC }\end{array}$ & $14.62 \mathrm{~b}$ & $0.72 \mathrm{c}$ & $15.35 \mathrm{~b}$ & $0.95 \mathrm{a}$ & $0.04 \mathrm{a}$ & $21.10 \mathrm{a}$ & $42.77 \mathrm{~b}$ \\
\hline $\begin{array}{l}\text { T. harzianum } \\
\text { ESALQ } 1306\end{array}$ & $17.83 \mathrm{a}$ & $1.09 \mathrm{a}$ & $18.92 \mathrm{a}$ & $0.94 \mathrm{a}$ & $0.05 \mathrm{a}$ & $16.28 \mathrm{a}$ & $50.20 \mathrm{a}$ \\
\hline $\begin{array}{l}\text { T. asperellum } \\
\text { URM } 5911\end{array}$ & $14.86 \mathrm{~b}$ & $0.85 \mathrm{~b}$ & $15.72 \mathrm{~b}$ & $0.89 \mathrm{a}$ & $0.05 \mathrm{a}$ & $18.18 \mathrm{a}$ & $44.23 \mathrm{~b}$ \\
\hline Control & $9.74 \mathrm{c}$ & $0.50 \mathrm{~d}$ & $10.26 \mathrm{c}$ & $0.94 \mathrm{a}$ & $0.05 \mathrm{a}$ & $18.21 \mathrm{a}$ & $30.18 \mathrm{c}$ \\
\hline CV (\%) & 15.38 & 17.98 & 14.62 & 10.32 & 24.09 & 25.56 & 13.89 \\
\hline
\end{tabular}

Averages followed by same lowercase letters in the column do not differ statistically, Scott-Knott test $(\mathrm{P} \leq 0.05) ;{ }^{1} \mathrm{BIO}=\mathrm{SDM}+\mathrm{RDM} ;{ }^{2} \mathrm{SMR}=$ $\mathrm{SDM} / \mathrm{BIO} ;{ }^{3} \mathrm{RMR}=\mathrm{RDM} / \mathrm{BIO} ;{ }^{4} \mathrm{~S} / \mathrm{R}=\mathrm{SDM} / \mathrm{RDM}$. 


\section{REFERENCES}

AKRAMI, M; GOLZARY, H; AHMADZADEH, M. 2011. Evaluation of different combinations of Trichoderma species for controlling Fusarium rot of lentil. African Journal of Biotechnology 10: 2653-2658.

AZARMI, R; HAJIEGHRARI, B; GIGLOU, A. 2011. Effect of Trichoderma isolates on tomato seedling growth response and nutrient uptake. African Journal of Biotechnology 10: 5850-5855.

AZEVEDO FILHO, JA; LUCON, CMM.; DUARTE, LML.; CHAVES, ALR; DONADELLI, A; ALEXANDRE, MAV; KANO, C. 2011. Efeito da aplicação de maravilha (Mirabilis jalapa L.), primavera (Bougainvillea spectabilis L.) e isolados de Trichoderma na produção de alface. Revista Brasileira de Plantas Medicinais 13: 612-618.

BARROS JÚNIOR, AP; BEZERRA NETO, F; SILVEIRA, LM; LINHARES, PCF; MOREIRA, JN; SANTOS, EC; OLIVEIRA, E. 2010. Qualidade pós-colheita de alface em função de diferentes tipos e quantidades de adubos verdes. Horticultura Brasileira 28: 1351-1357.

BENÍTEZ, T; RINCÓN, AM; LIMÓN, MCL; CODÓN, AC. 2004. Biocontrol Mechanisms of Trichoderma Strains, International Microbiology 7: 249-260.

BLIND, AD; SILVA FILHO, DF. 2015. Desempenho produtivo de cultivares de alface americana na estação seca da Amazônia Central. Bioscience Journal 31: 404-414.

CARVALHO, DDC; GERALDINE, AM; LOBO JUNIOR, M; MELLO, SCM. 2015a. Biological control of white mold by Trichoderma harzianum in common bean under field conditions.Pesquisa Agropecuária Brasileira 50: 1220-1224.

CARVALHO, DDC; MELLO, SCM; LOBO JÚNIOR, M; GERALDINE, AM. 2011a. Biocontrol of seed pathogens and growth promotion of common bean seedlings by Trichoderma harzianum. Pesquisa Agropecuária Brasileira 46: 822-828.

CARVALHO, DDC; MELLO, SCM; MARTINS, I; LOBO JUNIOR, M. 2015b. Biological control of Fusarium wilt on common beans by in-furrow application of Trichoderma harzianum. Tropical Plant Pathology 40 (6):
375-381.

CARVALHO, DDC; OLIVEIRA, DF; CAMPOS, VP; PASQUAL, M. 2011b. Selection of phytotoxin producing rhizobacteria. Anais da Academia Brasileira de Ciências 83: 1091-1096.

CEASA-GO.2016. Análise conjuntural 2016. Relatório n. 41. Goiânia: CEASA-GO. 393p.

CHACÓN, MR; RODRIGUÉZ-GALAN, O; BENITEZ, T; SOUSA, S; REY, M; LLOBELL, A; DELGADO-JARANA, J. 2007. Microscopic and transcripto mean alyses of early colonization of tomato roots byTrichoderma harzianum. International Microbiology 10: 19-27.

FERREIRA, AG; BORGHETTI, F. 2004. Germinação: do básico ao aplicado. Artmed: Porto Alegre, 324p.

FERREIRA, DF. 2011. Sisvar: a computer statistical analysis system. Ciência e Agrotecnologia 35: 1039-1042.

GUIMARÃES, GR; PEREIRA, FS; MATOS, FS; MELLO, SCM; CARVALHO, DDC. 2014. Supression of seedborne Cladosporium herbarum on common bean seed byTrichoderma harzianum and promotion of seedling development. Tropical Plant Pathology 39: 401-406.

HAJIEGHRARI, B. 2010. Effects some Iranian Trichoderma isolates on maize seed germination and seedling vigor. AfricanJournal of Biotecnology 9: 4242-4347.

HARTWIGSEN, J; EVANS, MR. 2000. Humic acid seed and substrate treatments promote seedling root development. Hortscience 35: 1231-1233.

HOFFMANN, CA; CHAGAS, LFB; SILVA, DP; CHAGAS JUNIOR, AF; SCHEIDT, GN. 2015. Potencial de antagonismo de isolados de Trichoderma sp. contra os isolados de Fusarium sp., in vitro. Revista Verde de Agroecologia e Desenvolvimento Sustentável 10: 236-242.

MACHADO, DFM; PARZIANELLO, RF; SILVA, ACF; ANTONIOLLI, ZI. 2012. Trichoderma no Brazil: O Fungo e o bioagente. Revista de Ciências Agrárias 35: 274-288.

MEDEIROS, DC; LIMA, BAB; BARBOSA, MR; ANJOS, RSB; BORGES, RD; CAVALCANTE NETO, JG; MARQUES, LF. 2007. Produção de mudas de alface com biofertilizantes e substratos. Horticultura Brasileira 25: 433-
436.

OLIVEIRA, JB; MUNIZ, PHPC; PEIXOTO, GHS; OLIVEIRA, TAS; DUARTE, EAA; RODRIGUES, F; CARVALHO, DDC. 2018. Promotion of seedling growth and production of wheat by using Trichoderma spp. Journal of Agricultural Science 10: 267-276.

SANTI,A; SCARAMUZZA, WLMP; NEUHAUS, A; DALLACORT, R; KRAUSE, W; TIEPPO, RC. 2013. Desempenho agronômico de alface americana fertilizada com torta de filtro em ambiente protegido. Horticultura Brasileira 31: 338-343.

SCHLINDWEIN, G; VARGAS, LK; LISBOA, BB; AZAMBUJA, AC; GRANADA, CE; GABIATTI, NC; PRATES, F; SUMPF, R. 2008. Influência da inoculação de rizóbios sobre a germinação e o vigor de plântulas de alface. Ciência Rural 38: 658-664.

SEDIYAMA, MAN; MAGALHÃES, IPB; VIDIGAL, SM; PINTO, CLO; CARDOSO, DSCP; FONSECA, MCM; CARVALHO, PL. 2016. Uso de fertilizantes orgânicos no cultivo de alface americana (Lactuca sativa $\mathrm{L}$.) 'Kaiser'. Revista Brasileira de Agropecuária Sustentável 6: 66-74.

SILVA, GBP; HECKLER, LI; SANTOS, RF; DURIGON, MR; BLUME, E. 2015. Identificação e utilização de Trichoderma spp. armazenados e nativos no biocontrole de Sclerotinia sclerotiorum. Revista Caatinga 28: 33-42.

SOUZA, PA; VENTURIN, N; MACEDO, RLG. 2006. Adubação mineral do ipê-roxo (Tabebuia impetiginosa). Ciência Florestal 16: 261-270

TRANI, PE; NOVO, MCSS; CAVALLARO JÚNIOR, ML; GONCALVES, C; MAGGIO, MA; GIUSTO, AB; VAILATI, ML. 2006. Desempenho de cultivares de alface sob cultivo protegido. Bragantia 65: 441-445.

WESAM, IA; SABER, KMG; YOUNES, MR; ABDULAZIZ, AA. 2017. Trichoderma harzianum WKY1: anindoleacetic acid producer for growth improvement and anthracnose disease control in sorghum, Biocontrol Science and Technology 27: 654-676.

YURI, JE; SOUZA, RJ; FREITAS, SAC; RODRIGUES, JC; MOTA, JH. 2002. Comportamento de cultivares de alface tipo americana em Boa Esperança. Horticultura Brasileira 20: 229- 232 . 